\title{
Maternal iron homeostasis: effect on placental development and function
}

\author{
Hannah Roberts ${ }^{1}$, Stephane L Bourque $\odot^{2}$ and Stephen J Renaud ${ }^{1,3}$ \\ ${ }^{1}$ Department of Anatomy and Cell Biology, Schulich School of Medicine and Dentistry, University of Western \\ Ontario, London, Ontario, Canada, ${ }^{2}$ Departments of Anesthesiology \& Pain Medicine, Pharmacology, and Pediatrics, \\ University of Alberta, Edmonton, Alberta, Canada and ${ }^{3}$ Children's Health Research Institute, Lawson Health \\ Research Institute, London, Ontario, Canada
}

Correspondence should be addressed to S L Bourque or S I Renaud; Email: sbourque@ualberta.ca or srenaud4@uwo.ca

\begin{abstract}
Iron is an essential mineral that participates in oxygen transport, DNA synthesis and repair, and as a cofactor for various cellular processes. Iron deficiency is the most common nutritional deficiency worldwide. Due to blood volume expansion and demands from the fetal-placental unit, pregnant women are one of the populations most at risk of developing iron deficiency. Iron deficiency during pregnancy poses major health concerns for offspring, including intrauterine growth restriction and long-term health complications. Although the underlying mechanisms remain unclear, maternal iron deficiency may indirectly impair fetal growth through changes in the structure and function of the placenta. Since the placenta forms the interface between mother and baby, understanding how the placenta changes in iron deficiency may yield new diagnostic indices of fetal stress in affected pregnancies, thereby leading to earlier interventions and improved fetal outcomes. In this review, we compile current data on the changes in placental development and function that occur under conditions of maternal iron deficiency, and discuss challenges and perspectives on managing the high incidence of iron deficiency in pregnant women.

Reproduction (2020) 160 R65-R78
\end{abstract}

\section{Introduction}

Iron is an essential mineral that participates in many cellular processes, including oxygen transport, DNA synthesis and repair, and as an essential cofactor for various enzymes. Iron deficiency (ID) is the most common nutrient deficiency worldwide (McLean et al. 2009). It occurs when iron demands chronically exceed intake, leading to progressive depletion of tissue iron stores, and eventually, functional iron. Since iron is required for hemoglobin $(\mathrm{Hb})$ synthesis, ID can result in anemia - a condition in which the quantity of circulating $\mathrm{Hb}$, and thus oxygen-carrying capacity, falls below clinical thresholds and begins to impact cellular function (Maria de Regil 2010). One of the populations most at risk for ID anemia is pregnant women, due to the increased iron requirements of pregnancy. Iron is essential to support placental and fetal growth and maintain increased maternal red blood cell mass. An estimated $38 \%$ of women develop anemia during pregnancy, including $22 \%$ in high-income countries, with most cases attributed to ID (Stevens et al. 2013, Lopez et al. 2016).

ID during pregnancy can detrimentally affect fetal health. ID increases the risk of fetal death, preterm birth, and intrauterine growth restriction, and is associated with altered growth trajectories and longterm cognitive, cardiovascular, metabolic, and immune system complications in affected offspring (Krantman et al. 1982, Doom \& Georgieff 2014, Alwan et al. 2015, Grandone et al. 2015). Despite repletion of iron stores in children through iron supplementation, health complications persist in children whose mothers exhibited ID during pregnancy, underscoring the importance of sufficient iron being supplied in utero for long-term health (Pasricha et al. 2013). Mechanisms through which maternal ID impairs fetal growth and results in long-term sequelae remain to be elucidated; however, the placenta may play a key role.

The placenta forms the interface between mother and fetus and supports fetal growth and development by facilitating respiratory gas, nutrient, and waste transport between maternal and fetal circulations, producing hormones, and providing immunological support. As an adaptiveorgan, the placenta can respond to environmental signals through alterations in structure and function, which in turn influence blood flow, nutrient transport, and hormone metabolism to optimize the intrauterine environment. While these adaptations may convey shortterm benefits, in some circumstances, they may impair long-term function and have profound impacts on a fetus' ability to cope in the intrauterine environment. Placental 
dysfunction may, therefore, connect adverse maternal nutrition and offspring health, and potentially be used as an 'early warning system' for fetal complications. In this review, we will briefly introduce placental development and discuss iron requirements during pregnancy. We will then summarize current knowledge detailing how ID affects placental development and function, and discuss new challenges and opportunities to address the impact of ID on placental development and pregnancy outcome.

\section{The placenta}

The human placenta is discoid-shaped, hemochorial (maternal blood directly contacts fetal chorion), and is composed of tissues derived from both mother and fetus. The maternal aspect of the placenta is the decidua basalis, which contains stromal cells, glands, leukocytes, and blood vessels (e.g. spiral arteries). The fetal aspect of the placenta is arranged in chorionic villi, which are highly branched structures consisting of an outer layer of syncytialized trophoblast and mononuclear cytotrophoblasts surrounding an inner core containing fibroblasts, macrophages, and blood vessels (Fig. 1). The syncytialized trophoblast layer is the major source of hormones necessary for pregnancy establishment and maintenance. At the tips of large anchoring villi, cytotrophoblasts differentiate into extravillous trophoblasts. Extravillous trophoblasts proliferate into stratified cell columns and then invade into the uterine



Figure 1 Schematic illustration of placental iron transport. Top: illustration of a human placenta. Bottom: diagram showing iron transport from the maternal circulation to the fetal circulation. BCRP, breast cancer resistance protein; CP, ceruloplasmin; DMT, divalent metal transporter-1; FLVCR1/2, feline leukemia subgroup C receptor 1/2; FPN, ferroportin; HO, heme oxygenases; Hp, hemopexin; LRP1, low-density lipoprotein receptor-related protein-1; PCBP, poly $(\mathrm{rC})$-binding protein; $\mathrm{PCFT}$, proton-coupled folate transporter; STEAP, six-transmembrane epithelial antigen of prostate; Tf, transferrin; TfR1, transferrin receptor 1; ZIP, ZRT/IRT-like protein; ZP, zyklopen. 
wall to modify spiral arteries and promote consistent, low-velocity maternal blood flow toward the space surrounding chorionic villi. Blood vessels in the villous core bring deoxygenated, nutrient-poor blood from the fetus. Oxygen and nutrients dissolved in maternal blood pass across the trophoblast layer into blood vessels within the villous core, where they are carried to the fetus. Carbon dioxide and wastes pass from fetal blood into the intervillous space to be carried away via endometrial veins. Substances can move across the placenta by simple diffusion (e.g. oxygen), facilitated diffusion (e.g. glucose), or active transport (e.g. iron). Placental nutrient transfer capacity can be influenced by a wide variety of factors, including villous surface area and thickness, the abundance and activity of transporters, concentration gradients between maternal and fetal blood, placental metabolism, and uteroplacental blood flow, all of which are sensitive to environmental stimuli (Tarrade et al. 2015).

A discoid-shaped, hemochorial placenta also features in many rodent species, including those commonly used in laboratory settings: mice and rats (referred to as 'laboratory rodents' unless specified otherwise) (Soares et al. 2012). Although there are inherent differences in placentation between humans and laboratory rodents (e.g. length of gestation, number of conceptuses, and organization of trophoblast subtypes within the placenta), there are also anatomical and functional similarities (Soncin et al. 2018). For instance, placentas of laboratory rodents are composed of both maternal and fetal compartments. The maternal compartment includes the decidua basalis and mesometrial triangle, and contains spiral arteries and a similar composition of cells to that found in humans. In laboratory rodents, the site at which nutrients are exchanged between maternal and fetal blood, referred to as the labyrinth zone because of its maze-like resemblance in cross-section, is compositionally similar to the chorionic villi in humans. Nutrients dissolved in maternal blood pass across three trophoblast layers (including two syncytialized layers) to access the fetal circulation. The junctional zone is a transitional region sandwiched between the labyrinth zone and decidua basalis. It is composed of stratified layers of trophoblasts, a subset of which invade into the maternal compartment and, particularly in rats, contribute to spiral artery transformation. Thus, the junctional zone is functionally analogous to extravillous trophoblasts in human placenta. The junctional zone also has an important endocrine function, which is a major difference between placentas of humans and laboratory rodents (Malassiné et al. 2003). Nevertheless, given the anatomical and functional similarities between human and laboratory rodent placentas and the capacity for experimental manipulation in the latter (Renaud et al. 2011), many studies have used mice and rats to deduce the impact of iron homeostasis on pregnancy outcome.
Consequently, although this review will emphasize the impact of iron homeostasis on human placental development, we will also discuss findings using mice, rats, and other species where appropriate.

\section{Iron requirements and regulation in pregnancy}

The maternal requirement for iron changes considerably during pregnancy to facilitate maternal blood volume expansion, placental development, and fetal growth (reviewed in Fisher \& Nemeth 2017). Most of this demand occurs in the third trimester, reaching an average daily iron requirement of approximately 4.4 mg/day (Milman 2006a). To accommodate the increased iron requirements, women entering pregnancy should have approximately $500 \mathrm{mg}$ of stored iron (Milman et al. 1999), yet only $20-35 \%$ of women of reproductive age are estimated to meet this threshold (Milman 2006b, Means 2020). It is, therefore, apparent why many women experience ID during pregnancy.

Several mechanisms enhance iron availability in the maternal circulation throughout pregnancy, including increased intestinal absorption of iron and mobilization of maternal iron reserves. Dietary iron exists in two forms: nonheme (predominantly from plant sources) and heme (from animal sources). As pregnancy progresses, maternal absorption of nonheme iron increases and heme absorption likely follows a similar trend (Barrett et al. 1994, Young et al. 2012). Maternal iron stores become mobilized during pregnancy from depots such as liver and spleen, as shown by studies using pregnant rodents (Hubbard et al. 2013, Gao et al. 2015). Additionally, iron-binding capacity of transferrin (Tf), which transports nonheme iron in blood, increases throughout gestation (Choi et al. 2000). Together, these processes facilitate maternal hematologic adaptation, and increase iron availability for the placenta and fetus.

The regulation of iron availability during pregnancy is dependent on hepcidin, a hormone produced mainly by hepatocytes that controls levels of circulating iron (Nemeth \& Ganz 2006). Multiple factors influence hepcidin production, including circulating and stored iron, erythropoietic activity, and inflammation (Sangkhae \& Nemeth 2017). Hepcidin binds to the iron export protein, ferroportin (FPN), and promotes its degradation, thereby triggering iron sequestration and decreased efflux into plasma from key sites, including intestine and liver (Fisher \& Nemeth 2017). In second and third trimesters, maternal hepcidin concentrations are decreased, presumably to increase iron availability and uptake by the placenta, which constitutes an important period of iron accretion for the fetus (van Santen et al. 2013, Bah et al. 2017). In a study of 19 pregnant women who ingested stable iron isotopes, net dietary nonheme and heme iron transferred to the fetus was inversely correlated with maternal serum hepcidin 
(Young et al. 2012). Not surprisingly, maternal hepcidin is lowest in pregnant women with ID (Rehu et al. 2010).

\section{Placental iron transport and regulation}

Fetal growth and development are dependent on active iron transport across the placenta, therefore this organ plays a crucial role in iron flux throughout pregnancy. Placental iron transport is controlled mainly by the syncytiotrophoblast. A detailed description of placental iron transport mechanisms has recently been reviewed (Sangkhae \& Nemeth 2019).

\section{Placental nonheme iron transport}

Nonheme iron is bound to Tf in maternal circulation. The iron-bound $T f$ binds to the $T f$ receptor (TfR) and undergoes unidirectional transport. Both TfR1 and TfR2 are expressed on the apical surface of the syncytiotrophoblast; however, the role of TfR2 remains undefined (McArdle et al. 2011). The iron-Tf-TfR1 complex is internalized via clathrinmediated endocytosis. Acidification of the vesicle causes iron to dissociate from $\mathrm{Tf}$ as $\mathrm{Fe}^{3+}$ and becomes reduced by ferrireductases to $\mathrm{Fe}^{2+}$. Potential ferrireductases include six-transmembrane epithelial antigen of prostate-3 (STEAP3) and STEAP4, which are highly expressed in the placenta (Ohgami et al. 2006). TfR and Tf return to the apical surface of syncytiotrophoblast, where Tf is recycled back into the maternal circulation. $\mathrm{Fe}^{2+}$ is transported from endosomes into the cytoplasm, possibly via divalent metal transporter-1 (DMT1), which has been implicated in maternal-fetal iron transfer (Chong et al. 2005). Interestingly, studies in mice suggest the likelihood of an alternative DMT1-independent iron-uptake pathway in the placenta, which may involve ZRT/IRT-like protein-14 (ZIP14), and ZIP8 (Gunshin et al. 2005).

Once in the cytosol, iron may be chaperoned by poly $(\mathrm{rC})$-binding protein (PCBP) to either be used for cellular processes, stored in ferritin, or transported to the basolateral surface of syncytiotrophoblast, where it is exported into the villous core via FPN. As ferritin levels are low in syncytiotrophoblast, most iron entering the placenta is likely used for cellular processes or transported to the fetus (Bastin et al. 2006). Once exported from the syncytiotrophoblast via FPN, iron may be delivered to fetal Tf via oxidation by placental ferroxidases which may include ceruloplasmin, hephaestin, and zyklopen (Danzeisen et al. 2000, Chen et al. 2010). Alternatively, non-Tf-bound iron is present in the fetal circulation, indicating that it may be transported directly across fetal endothelial cells, although this mechanism is unknown (Evans et al. 2011).

\section{Placental heme iron transport}

Placental expression of putative heme influx transporters includes proton-coupled folate transporter (PCFT)/ heme carrier protein-1 (HCP1), breast cancer resistance protein (BCRP), and feline leukemia subgroup C receptor-2 (FLVCR2) (Maliepaard et al. 2001, Qiu et al. 2006, Duffy et al. 2010). Low-density lipoprotein receptor-related protein-1 (LRP1) is highly expressed in placenta and may also facilitate heme uptake by recognizing heme complexed to a high-affinity hemebinding plasma protein, hemopexin (Hvidberg et al. 2005). Once imported, heme iron can be processed by heme oxygenases, releasing iron into the cytosol, or may be directly exported by FLVCR1, which may serve to prevent heme toxicity (Jaacks et al. 2011, Levytska et al. 2013). The functional significance of heme iron transport across the placenta is largely unknown. However, following maternal ingestion of ${ }^{57} \mathrm{Fe}$-heme and ${ }^{58} \mathrm{Fe}$-nonheme iron, a greater proportion of ${ }^{57} \mathrm{Fe}$ was detected in neonates, suggesting that heme-based iron is more efficiently transferred compared to nonheme iron (Young et al. 2012). Although there are multiple factors that may account for increased enrichment of heme versus nonheme iron in neonatal blood, it is nevertheless apparent that heme is an important source of iron for the fetus.

\section{Regulation of placental iron transport}

Several factors influence transport of nutrients (including iron) across the placenta, including uteroplacental and umbilical hemodynamics, placental surface area, metabolism, and expression/activity of transporters. In response to changes in cytosolic iron status, iron regulatory proteins bind to untranslated regions (UTRs) of transcripts encoding transporters and storage proteins (e.g. TfR1, DMT1, ferritin, and FPN), as reviewed in (Lipiński et al. 2013). In general, binding of iron regulatory proteins to the $3^{\prime}$-UTR increases mRNA stability (e.g. for TfR1 and DMT1), whereas binding to the $5^{\prime}$-UTR prevents translation (e.g. for ferritin and FPN). Thus, when cytosolic iron levels are plentiful, iron storage and export are stimulated and import is inhibited.

Maternal and fetal hepcidin levels influence placental iron trafficking. Hepcidin may interact with FPN to facilitate its internalization from the basolateral membrane of syncytiotrophoblast, and also downregulates TfR1 expression in mouse placenta (Martin et al. 2004, Nemeth et al. 2004). Notably, in mouse embryos that overexpress hepcidin, either as a consequence of transgenic hepcidin overexpression or mutations in the hepcidin regulator matriptase-2, placental FPN is downregulated resulting in severe fetal ID (Nicolas et al. 2002, Willemetz et al. 2014). Additionally, mouse embryos lacking hereditary hemochromatosis protein (HFE), a protein that promotes hepcidin production, exhibit increased placental expression of TfR1, DMT1, and FPN (Balesaria et al. 2012). HFE is also expressed on the apical surface of 
syncytiotrophoblast. In addition to stimulating hepcidin production, it may negatively regulate iron uptake by blocking TfR1 binding to Tf, as it does in hepatocytes (Parkkila et al. 1997, Gruper et al. 2005). In rats, fetal hepcidin levels tightly correlate with maternal liver iron levels, more so even than the association between maternal hepcidin and maternal iron status (Gambling et al. 2009). This may help to ensure fetal iron demands are met during pregnancy. Fetal hepcidin is also upregulated during maternal inflammation, possibly as a protective mechanism to limit iron availability to pathogenic bacteria (Fisher et al. 2020). Notably, hepcidin is also expressed by the placenta at low levels, but its role is unclear (Evans et al. 2011). No correlation exists between placental hepcidin expression and either maternal or neonatal iron status, nor with placental iron transporter expression (Rehu et al. 2010, Best et al. 2016). Similarly, placental hepcidin in pregnant rats is not associated with iron content of maternal diet, or with maternal or fetal liver iron content; in mice, placental hepcidin does not correlate with fetal iron endowment in normal pregnancy or in iron-deficient states (Gambling et al. 2009, Sangkhae et al. 2020a,b).

\section{Maternal ID: effect on the placenta}

\section{Transplacental iron and nutrient transport}

In maternal ID, placental iron transfer is a balancing act to ensure that sufficient iron is available to support its own functions and delivered to the fetus despite low levels in maternal blood. Table 1 summarizes alterations in placental expression of proteins involved in iron transport and metabolism in relation to iron status. The placental protein that is most frequently reported to exhibit altered levels relative to iron status is TfR1. Increased TfR1 expression is frequently reported in placentas from ID pregnancies, and is recapitulated in human trophoblast cells and cell-lines cultured in the presence of the iron chelator, desferoxamine (Kroos et al. 1996, Georgieff et al. 1999, Gambling et al. 2001, Li et al. 2008, 2012, Young et al. 2010, Garcia-Valdes et al. 2015, Best et al. 2016, Sangkhae et al. 2020a). Likewise, increased placental TfR1 expression is evident in pregnant rodents fed ID diets (Gambling et al. 2009, Balesaria et al. 2012, Cornock et al. 2013), whereas rodents fed an iron-replete diet or given parenteral iron supplementation exhibit decreased placental TfR1 expression (Martin et al. 2004, Balesaria et al. 2012). Thus, dynamic expression of TfR 1 by the placenta is potentially a key adaptation to guarantee appropriate uptake of iron from maternal blood.

Expression of other proteins involved in iron transport or metabolism has also been measured in maternal ID, although patterns are less clear. Placental expression of DMT1 is reported to be increased in some studies using rodent models of maternal ID, which may facilitate intracellular iron trafficking (Gambling et al.
2001, Cornock et al. 2013); although in other studies, no change in DMT1 was detected (Sangkhae et al. 2020a). In placentas collected from mothers with mildto-moderate anemia, no change in FPN expression is evident (Li et al. 2008, Best et al. 2016, Sangkhae et al. 2020a). However, in placentas collected from mice exposed to severe iron deficiency, or primary human trophoblasts treated with chelating agents, FPN expression is paradoxically reduced, suggesting that the placenta may sequester iron to preserve its own metabolic function rather than ensure fetal sustenance (Sangkhae et al. 2020a).

Maternal ID may also affect the expression of putative heme transporters. In pregnant adolescents, maternal anemia is associated with decreased expression of the placental heme export protein FLVCR1 (Jaacks et al. 2011). Fetal iron status more closely reflects the expression of the placental heme transporters FLVCR1 and PCFT than with nonheme transporters (Best et al. 2016), suggesting that heme transporters may respond to fetal iron demand rather than maternal iron availability. Given that the placenta efficiently uptakes heme iron, a better understanding of placental heme transport during normal and ID pregnancies is warranted.

In addition to increased expression of placental iron transporters, maternal adaptations also occur that facilitate iron availability for the placenta (Cao \& Fleming 2016). In rat models of ID, anemic dams exhibit increased intestinal absorption of iron, reduced liver iron content, and decreased maternal hepcidin expression compared to controls (Gambling et al. 2004, 2009, Cornock et al. 2013). Despite various adaptive changes in maternal metabolism and placental transport to optimize iron transfer to the fetus, babies born from severely anemic women have lower cord $\mathrm{Hb}$ levels compared to controls (Kumar et al. 2008, El-Farrash et al. 2012). Thus, under conditions of moderate iron deficiency, placental iron transport may be accelerated in favor of fetal demands. However, there appears to be a threshold of maternal iron status when a sufficient supply of iron cannot be delivered to the fetus, at which point the placenta establishes a new hierarchy in which iron is prioritized for its own function rather than delivered to the fetus.

Appropriate fetal growth and development also depend on the availability of nutrients, including glucose, amino acids, and fatty acids. Dysfunction in the transplacental transport of these nutrients may contribute to intrauterine growth restriction and other complications observed in maternal ID. In rats, maternal ID causes reduced fetal growth, correlating with decreased fetal plasma levels of triacylglycerol, cholesterol, and several amino acids, including taurine, phenylalanine, and tyrosine. Maternal plasma levels of these nutrients are unaffected, suggesting impaired placental transport (Lewis et al. 2001a). However, no studies to date have directly assessed placental expression or activity of nutrient transporters in the context of maternal ID. 
Table 1 Expression of factors implicated in placental iron trafficking during ID.

\begin{tabular}{|c|c|c|c|c|c|}
\hline \multirow[b]{2}{*}{ Name } & \multirow[b]{2}{*}{ Gene } & \multicolumn{4}{|c|}{ Changes in mRNA and protein expression } \\
\hline & & Human Studies & References & Animal studies & References \\
\hline \multicolumn{6}{|l|}{ Iron influx } \\
\hline TfR1 & TFRC & $\begin{array}{l}\uparrow \text { expression in human } \\
\text { placentas } \\
\uparrow \text { expression in BeWo cells } \\
\text { and primary trophoblasts } \\
\text { exposed to DFO }\end{array}$ & $\begin{array}{l}\text { Kroos et al. (1996), Georgieff } \\
\text { et al. (1999), Gambling et al. } \\
\text { (2001), Li et al. (2008, 2012), } \\
\text { Young et al. (2010), Garcia- } \\
\text { Valdes et al. (2015), Best et al. } \\
\text { (2016), Sangkhae et al. (2020a) }\end{array}$ & $\begin{array}{l}\uparrow \text { expression in rat } \\
\text { placentas }\end{array}$ & $\begin{array}{l}\text { Gambling et al. } \\
\text { (2009), Balesaria } \\
\text { et al. (2012), } \\
\text { Cornock et al. } \\
(2013)\end{array}$ \\
\hline HFE & $H F E$ & & & $\begin{array}{l}\leftrightarrow \text { mRNA } \\
\text { expression in rat } \\
\text { and mouse } \\
\text { placentas }\end{array}$ & $\begin{array}{l}\text { Gambling et al. } \\
\text { (2009), Sangkhae } \\
\text { et al. (2020a) }\end{array}$ \\
\hline BCRP & $B C R P$ & $\begin{array}{l}\leftrightarrow \text { protein expression in } \\
\text { human placentas }\end{array}$ & Jaacks et al. (2011) & & \\
\hline \multicolumn{6}{|c|}{ Intracellular iron trafficking and storage } \\
\hline DMT1 & SLC11A2 & $\begin{array}{l}\uparrow \text { expression in human } \\
\text { placentas } \\
\uparrow \text { expression in BeWo cells } \\
\text { exposed to DFO }\end{array}$ & $\begin{array}{l}\text { Gambling et al. (2001), Venkata } \\
\text { Surekha et al. (2020) }\end{array}$ & $\begin{array}{l}\leftrightarrow \text { mRNA } \\
\text { expression in } \\
\text { mouse placentas } \\
\uparrow \text { mRNA expression } \\
\text { in rat placentas }\end{array}$ & $\begin{array}{l}\text { Cornock et al. } \\
\text { (2013), Sangkhae } \\
\text { et al. (2020a) }\end{array}$ \\
\hline Ferritin & $\begin{array}{l}\text { FTH1 (heavy } \\
\text { chain), FTL } \\
\text { (light chain) }\end{array}$ & $\begin{array}{l}\downarrow \text { mRNA expression in } \\
\text { human placentas }\end{array}$ & Li et al. (2008) & $\begin{array}{l}\leftrightarrow \text { in expression in } \\
\text { rat placentas }\end{array}$ & $\begin{array}{l}\text { Gambling et al. } \\
(2009)\end{array}$ \\
\hline \multicolumn{6}{|l|}{ Iron efflux } \\
\hline FPN & SLC 40A1 & $\begin{array}{l}\leftrightarrow \text { or } \uparrow \text { protein expression in } \\
\text { human placentas } \\
\uparrow \text { expression in BeWo cells } \\
\text { exposed to DFO } \\
\downarrow \text { protein expression in } \\
\text { trophoblast cells exposed to } \\
\text { DFO }\end{array}$ & $\begin{array}{l}\text { Li et al. (2008, 2012), Best et al. } \\
\text { (2016), Sangkhae et al. (2020a), } \\
\text { Venkata Surekha et al. (2020) }\end{array}$ & $\begin{array}{l}\leftrightarrow \text { in mRNA } \\
\text { expression in rat } \\
\text { and mouse } \\
\text { placentas } \\
\downarrow \text { protein expression } \\
\text { in mouse } \\
\text { placentas }\end{array}$ & $\begin{array}{l}\text { Gambling et al. } \\
(2001), \text { Cornock } \\
\text { et al. }(2013), \\
\text { Sangkhae et al. } \\
(2020 a)\end{array}$ \\
\hline Ceruloplasmin & $C P$ & $\begin{array}{l}\leftrightarrow \text { in mRNA expression in } \\
\text { human placentas } \\
\leftrightarrow \text { in mRNA expression in } \\
\text { BeWo cells exposed to } \\
\text { DFO } \\
\uparrow \text { protein expression in BeWo } \\
\text { cells exposed to DFO }\end{array}$ & $\begin{array}{l}\text { Danzeisen et al. (2000), Li et al. } \\
\text { (2008), Best et al. (2016) }\end{array}$ & $\begin{array}{l}\leftrightarrow \text { in mRNA } \\
\text { expression in rat } \\
\text { placentas }\end{array}$ & $\begin{array}{l}\text { Fleming and Gitlin } \\
\text { (1990) }\end{array}$ \\
\hline Hephaestin & $H E P H$ & $\begin{array}{l}\uparrow \text { expression in BeWo cells } \\
\text { exposed to DFO }\end{array}$ & Li et al. (2012) & & \\
\hline Zyklopen & $Z P$ & $\begin{array}{l}\uparrow \text { expression in human } \\
\text { placentas }\end{array}$ & Venkata Surekha et al. (2020) & $\begin{array}{l}\leftrightarrow \text { in mRNA } \\
\text { expression in } \\
\text { mouse placentas }\end{array}$ & $\begin{array}{l}\text { Sangkhae et al. } \\
\text { (2020a) }\end{array}$ \\
\hline FLVCR1 & FLVCR1 & $\begin{array}{l}\downarrow \text { protein expression in } \\
\text { human placentas }\end{array}$ & Jaacks et al. (2011) & $\begin{array}{l}\leftrightarrow \text { in mRNA } \\
\text { expression in } \\
\text { mouse placentas }\end{array}$ & $\begin{array}{l}\text { Sangkhae et al. } \\
(2020 a)\end{array}$ \\
\hline
\end{tabular}

$\uparrow=$ Increased; $\leftrightarrow=$ No change; $\downarrow=$ Decreased; BCRP, breast cancer resistance protein; DMT1, divalent metal transporter 1; FLVCR1, feline leukemia virus subgroup $\mathrm{C}$ receptor 1 ; FPN, ferroportin; HFE, human hemochromatosis protein; TfR1, transferrin receptor 1 .

\section{Placental hypoxia, oxidative stress, and inflammation}

Hypoxia is a condition in which oxygen availability is reduced in cells or tissues. Since ID restricts $\mathrm{Hb}$ synthesis and oxygen transport, hypoxia is a potential consequence. Cells adapt to hypoxic conditions in part through stabilization of hypoxia-inducible factor alpha (HIFA) subunits, which interact with HIFA subunits to alter transcription of numerous genes that alter cell growth, metabolism, and survival. Stabilization of HIFA subunits is facilitated by reduced activity of prolyl hydroxylases, which are enzymes that hydroxylate HIFA when oxygen is replete, leading to its ubiquitination and degradation. Expression of HIF1A in the placenta is high in early pregnancy due to the low oxygen environment in which the placenta develops, and in normal circumstances expression declines by the end of the first trimester as oxygen tension increases (letta et al. 2006). However, in ID pregnancies, term placentae exhibit increased expression of HIF1A (Michalitsi et al. 2015). Likewise, in rat models of ID anemia, no change in mRNA expression of Hif1a in placenta is evident, but higher HIF1 A protein expression is detected (Lewis et al. 2001b, Toblli et al. 2012). Whether the increased HIF1A expression is attributed to hypoxia per se is unclear, because iron is a critical cofactor for prolyl hydroxylase activity (Bishop \& Ratcliffe 2015), and therefore HIF1A expression may be increased irrespective of oxygen 
levels (Woo et al. 2006). Indeed, using pimonidazole, which forms stable adducts with thiol groups of proteins in hypoxic cells, Woodman et al. found no evidence of placental hypoxia with maternal ID in pregnant rats, despite robust signals in various fetal organs (Woodman et al. 2017). Notwithstanding, the increased placental HIF1A may contribute to dysregulated expression of genes, such as those encoding inflammatory cytokines, which affect placental function and contribute to pregnancy complications (Gambling et al. 2002).

Oxidative stress is characterized by amplified production of reactive oxygen species beyond the capacity of antioxidant defense mechanisms, and is a normal occurrence throughout pregnancy (Mannaerts et al. 2018). As gestation advances, antioxidant defenses are enhanced to prevent oxidative damage to the placenta and fetus (Furukawa et al. 2016). In pregnant rat models of ID anemia, increased oxidative stress, lipid peroxidation, mitochondrial damage, and inflammatory cytokine production (e.g. tumor necrosis factor (TNF) and interleukin-6) is evident (Gambling et al. 2002, Walter et al. 2002, Toblli et al. 2012). Like the case with prolyl hydroxylases described above, iron is an essential cofactor for several antioxidant enzymes, including catalase. ID may thus impair the function of antioxidant defenses, exacerbating generation of reactive oxygen species and contributing to placental damage and dysfunction.

\section{Placental structure}

Since the placenta forms the interface between mother and fetus, its structure is a key determinant for oxygen and nutrient delivery to the fetus. The efficiency of nutrient and oxygen transfer to the fetus can be affected by changes in the total surface area available for exchange, thickness of the placental exchange surface, proportion of specialized placental regions, and vascularization. Therefore, the impact of maternal ID on placental structure is an important consideration.

When compared to fetal/neonatal weight, placental weight can be used as a proxy for placental efficiency, and an indication of how placental development and function has adapted to sustain fetal requirements (Fowden et al. 2009). Studies in both humans (Table 2) and animals (Table 3) show that maternal ID has an effect on placental weight and placental:fetal birth weight ratios. For example, several studies suggest that placental weight and placental:fetal weight ratios increase with maternal anemia (Beischer et al. 1970, Godfrey et al. 1991, Lao \& Wong 1997, Lao \& Tam 2000, Huang et al. 2001, Baptiste-Roberts et al. 2008, Lelic et al. 2014, Larsen et al. 2016). Among these studies, two were conducted using large cohorts of 8648 (Godfrey et al. 1991), and 57,062 (Larsen et al. 2016) human pregnancies, in which a negative correlation between placental weight and maternal $\mathrm{Hb}$ concentration was reported. It is possible that decreased iron and/or $\mathrm{Hb}$ evokes compensatory placental hypertrophy that increases surface area and enhances oxygen and nutrient exchange. Conversely, some studies have found no correlation between low $\mathrm{Hb}$ and placental weight (Reshetnikova et al. 1995) or decreased placental weights in anemic mothers (Rusia et al. 1988, Mongia et al. 2011, Kiran et al. 2015). Multiple factors may account for these discrepancies, including severity of anemia, timing of anemia onset, number of samples analyzed, ethnic populations, and possibility of maternal malnutrition or other nutritional deficits. In some cases, gestational age was not controlled, which confounds the interpretation of placental size and its relationship to fetal weight.

Rodents fed iron-deficient diets have been used to study the impact of ID anemia on pregnancy outcome. In these models, diets lacking iron are invariably associated with reduced fetal size (Lewis et al. 2001a, Gambling et al. 2002, Toblli et al. 2012, Woodman et al. 2017, 2018). However, conflicting effects of maternal anemia on placental weight have been reported, with many studies showing an increase in placental weight (Lewis et al. 2001a,b, Gambling et al. 2009, Woodman et al. 2017, 2018), and others reporting a decrease in placental weight (Toblli et al. 2012). As in the clinical studies, the differing effects may relate to the duration and severity of anemia. Low maternal iron and/or $\mathrm{Hb}$ may result in a compensatory hypertrophic response by the placenta to offset reduced oxygen or iron supply to the fetus. However, there may be a critical threshold of maternal iron and $\mathrm{Hb}$, below which placental oxidative stress, inflammation, and damage occur, hindering the capacity of the placenta to adapt.

Maternal ID is also associated with altered placental composition and morphology. In placentas exposed to ID, increased placental vascularization, capillary density, and dilation of villous sinusoids is observed (Reshetnikova et al. 1995, Burton et al. 1996, Kadyrov et al. 1998, Mongia et al. 2011, Lelic et al. 2014, Lelić et al. 2014). Such changes are a principal adaptation of the placenta to hypoxia or result from differences in hemodynamic forces during fetal development (Stanek 2013). Indeed, fetal cardiovascular adaptations have been associated with maternal anemia in sheep, including increased heart weight and cardiac output, which may explain altered placental capillary vascularization (Davis \& Hohimer 1991). Placentas exposed to maternal ID have smaller placental villous trees and thinner chorionic villous membranes, the latter possibly an adaptation to maintain the diffusion capacity of the exchange surface (Reshetnikova et al. 1995). Similar results are observed in rat models of maternal ID, in which the labyrinth zone (the region of rodent placentas where nutrients and gases are exchanged between maternal and fetal blood) is reduced in thickness (Awad et al. 2017). 


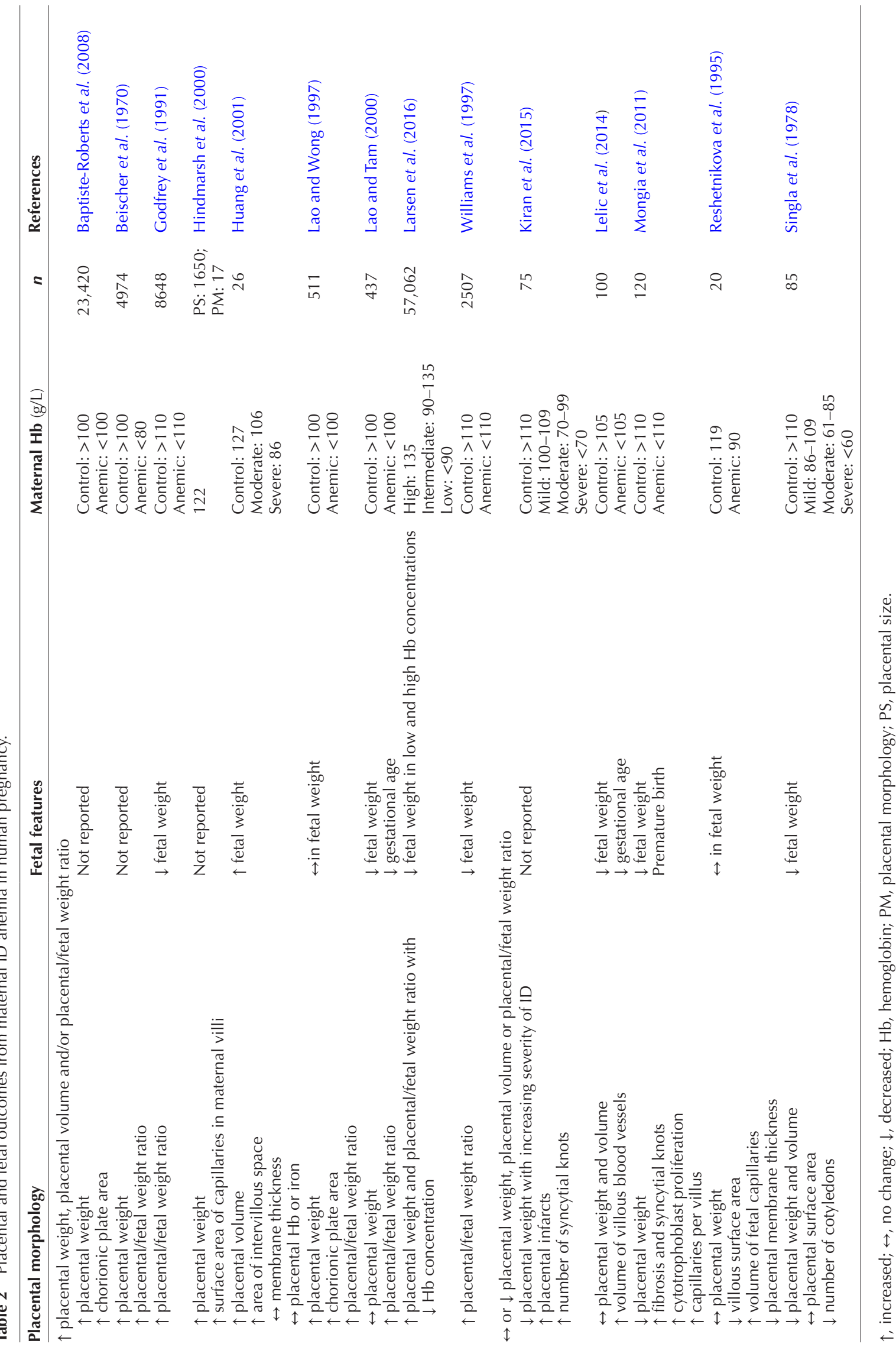







Another feature of placentas exposed to maternal ID is an increased number of placental infarcts, syncytial knots, and fibrinoid necrosis, which could affect functional villous mass (Begum et al. 1970, Huang et al. 2001, Mongia et al. 2011, Nausheen Rumana 2012, Kiran et al. 2015). These features are typically associated with maternal vascular malperfusion resulting from insufficient or pulsatile uteroplacental blood flow and reduced oxygen supply, which may contribute to the increased incidence of adverse pregnancy outcomes in maternal ID. Women with maternal ID also exhibit increased cytotrophoblast proliferation, possibly to facilitate syncytiotrophoblast repair in response to ischemia (Kosanke et al. 1998, Biswas et al. 2014). Together, these studies demonstrate that maternal ID impacts several aspects of placental structure.

\section{Challenges and opportunities}

Although screening for ID is recommended for all pregnant women (Abdulrehman et al. 2019), a study commissioned by the United States Preventive Services Task Force reported that the evidence is inconclusive about the efficacy of supplementation for improving maternal and infant health outcomes despite improving maternal hematological indices (Cantor et al. 2015, Achebe \& Gafter-Gvili 2017). Routine screening for ID and iron supplementation is only recommended in women of reproductive age if anemia is diagnosed. Consequently, many women enter pregnancy with marginal iron stores and do not receive treatment until they exhibit symptoms of severe anemia. Treatment recommendations for maternal ID anemia include increased dietary intake of iron-rich foods and oral iron supplementation, most commonly with ferrous sulfate. Although inexpensive and readily available in many developed countries, oral iron supplementation causes gastrointestinal discomfort in more than $70 \%$ of those to whom it is prescribed, including metallic taste, gastric irritation, and worsening constipation, resulting in poor adherence (Tolkien et al. 2015). Furthermore, serum hepcidin levels are increased for approximately $48 \mathrm{~h}$ after ingestion of iron supplements, restricting iron absorption from the intestine (Moretti et al. 2015). Prolonged-release preparations of oral iron supplements may offer solutions to these issues while conferring similar bioavailability (Santiago 2012). Other formulations are available that purport enhanced efficacy and tolerability (iron-polysaccharide complexes, heme iron polypeptide), though these claims have been questioned in light of several clinical trial outcomes (Santiago 2012, Moe et al. 2019). Although more expensive, intravenous iron has lower toxicity and is more effective than orallyadministered iron (Auerbach et al. 2017); although it has not been rigorously tested in pregnant women and it is uncertain how well it is tolerated by the mother, placenta, and fetus.

Given the high incidence of maternal ID and its potential impacts on placental and fetal health, there is urgent need to better understand placental iron metabolism and develop strategies to prevent, detect, and treat maternal ID during pregnancy. Early detection

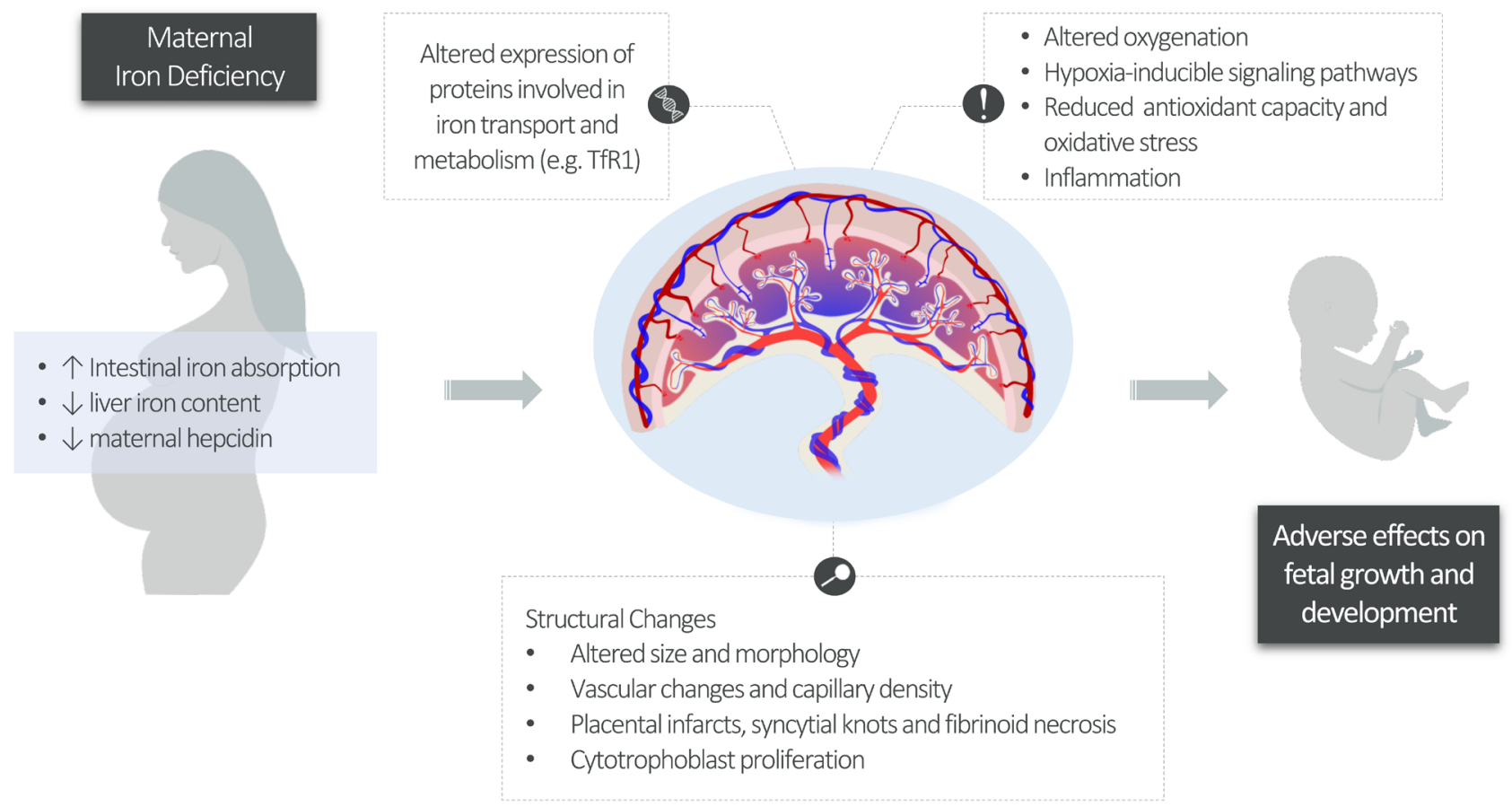

Figure 2 Schematic depicting the potential impact of maternal iron deficiency on the placenta. 
of ID can be improved by implementing routine prenatal screening, irrespective of $\mathrm{Hb}$ level. Public health strategies to prevent ID include improvements in dietary diversity, food fortification with iron and other micronutrients, and distribution of iron-containing supplements; although indiscriminate iron supplementation may be problematic due to gastric irritation and potential toxicity described previously, and may be deleterious in regions where certain infectious diseases are prevalent. Other public health strategies include better control of infections like malaria that compromise red blood cell integrity, and access to education for reproductive health and family planning. Additionally, a better understanding of how ID affects placental and fetal development may lead to identification of biomarkers that better reflect fetal/ placental distress in ID (e.g. ratio of placental FPN/TfR1 (Sangkhae et al. 2020a)), and provide opportunities to intervene in utero, thereby reducing the risk of longterm health complications. Accessible and cost-effective interventions will help to reduce the burden of maternal ID and long-term consequences on offspring health.

\section{Conclusions}

Iron is a crucial mineral for many cellular and physiological processes. ID during pregnancy remains a global problem with significant health implications for both mothers and offspring. Depending on the severity and duration, low levels of maternal iron and $\mathrm{Hb}$ may result in decreased oxygenation that progress to hypoxic and inflammatory conditions in the placenta. This may stimulate placental hypertrophy, increased vascularization, structural changes at the fetal-maternal exchange surface, and altered expression or activity of nutrient transporters (Fig. 2 ). Future studies are needed to clarify structural and functional modifications in the placenta during maternal ID, and determine whether these modifications are adaptive responses striving to maintain iron sustenance and support fetal growth and development, or pathological changes contributing to maternal and fetal adversity. Since the placenta forms the interface between mother and baby, understanding how the placenta changes in ID may yield new diagnostic indices of fetal stress in affected pregnancies, thereby leading to earlier interventions and improved fetal outcomes.

\section{Declaration of interest}

The authors declare that there is no conflict of interest that could be perceived as prejudicing the impartiality of the research reported.

\section{Funding}

This work was supported by the Canadian Institutes of Health Research Project Grant (152983, S J R).

\section{Author contribution statement}

$\mathrm{HR}$ and S J R wrote the initial draft of the manuscript. S L B and S J R critically revised the manuscript. All authors read, revised, and approved the final manuscript.

\section{Acknowledgement}

The authors wish to thank Jenna Yuen for illustrative assistance.

\section{References}

Abdulrehman J, Lausman A, Tang GH, Nisenbaum R, Petrucci J, Pavenski K, Hicks LK \& Sholzberg M 2019 Development and implementation of a quality improvement toolkit, iron deficiency in pregnancy with maternal iron optimization (IRON MOM): a before-and-after study. PLoS Medicine 16 e1002867. (https://doi.org/10.1371/journal.pmed.1002867)

Achebe MM \& Gafter-Gvili A 2017 How I treat anemia in pregnancy: iron, cobalamin, and folate. Blood 129 940-949. (https://doi.org/10.1182/ blood-2016-08-672246)

Alwan NA, Cade JE, McArdle HJ, Greenwood DC, Hayes HE \& Simpson NAB 2015 Maternal iron status in early pregnancy and birth outcomes: insights from the Baby's vascular health and iron in pregnancy study. British Journal of Nutrition 113 1985-1992. (https:// doi.org/10.1017/S0007114515001166)

Auerbach M, James SE, Nicoletti M, Lenowitz S, London N, Bahrain HF, Derman R \& Smith S 2017 Results of the first american prospective study of intravenous iron in oral iron-intolerant iron-deficient gravidas. American Journal of Medicine 130 1402-1407. (https://doi. org/10.1016/j.amjmed.2017.06.025)

Awad O, Malek A \& Ogeng'o J 2017 Differential effects of chronic iron deficiency anaemia on junctional and labyrinthine zones of placenta in Sprague dawely rat. Anatomy Journal of Africa 6 840-846.

Bah A, Pasricha SR, Jallow MW, Sise EA, Wegmuller R, Armitage AE, Drakesmith H, Moore SE \& Prentice AM 2017 Serum hepcidin concentrations decline during pregnancy and may identify iron deficiency: analysis of a longitudinal pregnancy cohort in the Gambia. Journal of Nutrition 147 1131-1137. (https://doi.org/10.3945/jn.116.245373)

Balesaria S, Hanif R, Salama MF, Raja K, Bayele HK, McArdle H \& Srai SKS 2012 Fetal iron levels are regulated by maternal and fetal Hfe genotype and dietary iron. Haematologica 97 661-669. (https://doi.org/10.3324/ haematol.2011.055046)

Baptiste-Roberts K, Salafia CM, Nicholson WK, Duggan A, Wang NY \& Brancati FL 2008 Maternal risk factors for abnormal placental growth: the national collaborative perinatal project. BMC Pregnancy and Childbirth 8 44. (https://doi.org/10.1186/1471-2393-8-44)

Barrett JF, Whittaker PG, Williams JG \& Lind T 1994 Absorption of nonhaem iron from food during normal pregnancy. BMJ 309 79-82. (https:// doi.org/10.1136/bmj.309.6947.79)

Bastin J, Drakesmith H, Rees M, Sargent I \& Townsend A 2006 Localisation of proteins of iron metabolism in the human placenta and liver. British Journal of Haematology 134 532-543. (https://doi.org/10.1111/j.13652141.2006.06216.x)

Begum M, Ara S, Kishwara S, Nurunnabi ASM \& Rayhan KA 1970 Microscopic changes of the placental components in maternal anaemia. Bangladesh Journal of Anatomy 8 59-63. (https://doi.org/10.3329/bja. v8i2.7017)

Beischer NA, Sivasamboo R, Vohra S, Silpisornkosal S \& Reid S 1970 Placental hypertrophy in severe pregnancy anaemia. Journal of Obstetrics and Gynaecology of the British Commonwealth 77 398-409. (https://doi.org/10.1111/j.1471-0528.1970.tb03541.x)

Best CM, Pressman EK, Cao C, Cooper E, Guillet R, Yost OL, Galati J, Kent TR \& O'Brien KO 2016 Maternal iron status during pregnancy compared with neonatal iron status better predicts placental iron transporter expression in humans. FASEB Journal 30 3541-3550. (https:// doi.org/10.1096/fj.201600069R)

Bishop T \& Ratcliffe PJ 2015 HIF hydroxylase pathways in cardiovascular physiology and medicine. Circulation Research 117 65-79. (https://doi. org/10.1161/CIRCRESAHA.117.305109) 
Biswas S, Meyur R, Adhikari A, Bose K \& Kundu P 2014 Placental changes associated with maternal anaemia. European Journal of Anatomy $\mathbf{1 8}$ 165-169.

Burton GJ, Reshetnikova OS, Milovanov AP \& Teleshova OV 1996 Stereological evaluation of vascular adaptations in human placental villi to differing forms of hypoxic stress. Placenta 17 49-55. (https://doi. org/10.1016/s0143-4004(05)80643-5)

Cantor AG, Bougatsos C, Dana T, Blazina I \& McDonagh M 2015 Routine iron supplementation and screening for iron deficiency anemia in pregnancy: a systematic review for the U.S. Preventive Services Task Force. Annals of Internal Medicine 162 566-576. (https://doi. org/10.7326/M14-2932)

Cao C \& Fleming MD 2016 The placenta: the forgotten essential organ of iron transport. Nutrition Reviews 74 421-431. (https://doi.org/10.1093/ nutrit/nuw009)

Chen H, Attieh ZK, Syed BA, Kuo YM, Stevens V, Fuqua BK, Andersen HS, Naylor CE, Evans RW, Gambling L et al. 2010 Identification of Zyklopen, a new member of the vertebrate multicopper ferroxidase family, and characterization in rodents and human cells. Journal of Nutrition 140 1728-1735. (https://doi.org/10.3945/jn.109.117531)

Choi JW, Im MW \& Pai SH 2000 Serum transferrin receptor concentrations during normal pregnancy. Clinical Chemistry 46 725-727. (https://doi. org/10.1093/clinchem/46.5.725)

Chong WS, Kwan PC, Chan LY, Chiu PY, Cheung TK \& Lau TK 2005 Expression of divalent metal transporter 1 (DMT1) isoforms in first trimester human placenta and embryonic tissues. Human Reproduction 20 3532-3538. (https://doi.org/10.1093/humrep/dei246)

Cornock R, Gambling L, Langley-Evans SC, McArdle HJ \& McMullen S 2013 The effect of feeding a low iron diet prior to and during gestation on fetal and maternal iron homeostasis in two strains of rat. Reproductive Biology and Endocrinology 11 32. (https://doi.org/10.1186/1477-782711-32)

Crowe C, Dandekar P, Fox M, Dhingra K, Bennet L \& Hanson MA 1995 The effects of anaemia on heart, placenta and body weight, and blood pressure in fetal and neonatal rats. Journal of Physiology 488 515-519. (https://doi.org/10.1113/jphysiol.1995.sp020986)

Danzeisen R, Ponnambalam S, Lea RG, Page K, Gambling L \& McArdle HJ 2000 The effect of ceruloplasmin on iron release from placental (BeWo) cells; evidence for an endogenous Cu oxidase. Placenta 21 805-812. (https://doi.org/10.1053/plac.2000.0582)

Davis LE \& Hohimer AR 1991 Hemodynamics and organ blood flow in fetal sheep subjected to chronic anemia. American Journal of Physiology 261 R1542-R1548. (https://doi.org/10.1152/ajpregu.1991.261.6.R1542)

Doom JR \& Georgieff MK 2014 Striking while the iron is hot: understanding the biological and neurodevelopmental effects of iron deficiency to optimize intervention in early childhood. Current Pediatrics Reports 2 291-298. (https://doi.org/10.1007/s40124-014-0058-4)

Duffy SP, Shing J, Saraon P, Berger LC, Eiden MV, Wilde A \& Tailor CS 2010 The Fowler syndrome-associated protein FLVCR2 is an importer of heme. Molecular and Cellular Biology 30 5318-5324. (https://doi. org/10.1128/MCB.00690-10)

El-Farrash RA, Ismail EAR \& Nada AS 2012 Cord blood iron profile and breast milk micronutrients in maternal iron deficiency anemia. Pediatric Blood and Cancer 58 233-238. (https://doi.org/10.1002/pbc.23184)

Evans P, Cindrova-Davies T, Muttukrishna S, Burton GJ, Porter J \& Jauniaux E 2011 Hepcidin and iron species distribution inside the firsttrimester human gestational sac. Molecular Human Reproduction 17 227-232. (https://doi.org/10.1093/molehr/gaq101)

Fisher AL \& Nemeth E 2017 Iron homeostasis during pregnancy. American Journal of Clinical Nutrition 106 1567S-1574S. (https://doi.org/10.3945/ ajcn.117.155812)

Fisher AL, Sangkhae V, Presicce P, Chougnet CA, Jobe AH, Kallapur SG, Tabbah S, Buhimschi CS, Buhimschi IA, Ganz T et al. 2020 Fetal and amniotic fluid iron homeostasis in healthy and complicated murine, macaque, and human pregnancy. JCI Insight 5 e135321. (https://doi. org/10.1172/jci.insight.135321)

Fleming RE \& Gitlin JD 1990 Primary structure of rat ceruloplasmin and analysis of tissue-specific gene expression during development. Journal of Biological Chemistry 265 7701-7707.

Fowden AL, Sferruzzi-Perri AN, Coan PM, Constancia M \& Burton GJ 2009 Placental efficiency and adaptation: endocrine regulation.
Journal of Physiology 587 3459-3472. (https://doi.org/10.1113/ jphysiol.2009.173013)

Furukawa S, Nakajima A \& Sameshima H 2016 The longitudinal change of extracellular antioxidant status during pregnancy using an electron spin resonance method. Journal of Maternal-Fetal and Neonatal Medicine 29 2994-2999. (https://doi.org/10.3109/14767058.2015.1112370)

Gambling L, Danzeisen R, Gair S, Lea RG, Charania Z, Solanky N, Joory KD, Srai SK \& McArdle HJ 2001 Effect of iron deficiency on placental transfer of iron and expression of iron transport proteins in vivo and in vitro. Biochemical Journal 356 883-889. (https://doi. org/10.1042/0264-6021:3560883)

Gambling L, Charania Z, Hannah L, Antipatis C, Lea RG \& McArdle HJ 2002 Effect of iron deficiency on placental cytokine expression and fetal growth in the pregnant rat. Biology of Reproduction 66 516-523. (https://doi.org/10.1095/biolreprod66.2.516)

Gambling L, Andersen HS, Czopek A, Wojciak R, Krejpcio Z \& McArdle HJ 2004 Effect of timing of iron supplementation on maternal and neonatal growth and iron status of iron-deficient pregnant rats. Journal of Physiology 561 195-203. (https://doi.org/10.1113/jphysiol.2004.068825)

Gambling L, Czopek A, Andersen HS, Holtrop G, Srai SKS, Krejpcio Z \& McArdle HJ 2009 Fetal iron status regulates maternal iron metabolism during pregnancy in the rat. American Journal of Physiology: Regulatory, Integrative and Comparative Physiology 296 R1063-R1070. (https://doi. org/10.1152/ajpregu.90793.2008)

Gao G, Liu SY, Wang HJ, Zhang TW, Yu P, Duan XL, Zhao SE \& Chang YZ 2015 Effects of pregnancy and lactation on iron metabolism in rats. BioMed Research International 2015 105325. (https://doi. org/10.1155/2015/105325)

Garcia-Valdes L, Campoy C, Hayes H, Florido J, Rusanova I, Miranda MT \& McArdle HJ 2015 The impact of maternal obesity on iron status, placental transferrin receptor expression and hepcidin expression in human pregnancy. International Journal of Obesity 39 571-578. (https:// doi.org/10.1038/ijo.2015.3)

Georgieff MK, Berry SA, Wobken JD \& Leibold EA 1999 Increased placental iron regulatory protein-1 expression in diabetic pregnancies complicated by fetal iron deficiency. Placenta 20 87-93. (https://doi. org/10.1053/plac.1998.0339)

Godfrey KM, Redman CW, Barker DJ \& Osmond C 1991 The effect of maternal anaemia and iron deficiency on the ratio of fetal weight to placental weight. British Journal of Obstetrics and Gynaecology 98 886-891. (https://doi.org/10.1111/j.1471-0528.1991.tb13510.x)

Grandone A, Marzuillo P, Perrone L \& Del Giudice EM 2015 Iron metabolism dysregulation and cognitive dysfunction in pediatric obesity: is there a connection? Nutrients 7 9163-9170. (https://doi.org/10.3390/ nu7115458)

Gruper Y, Bar J, Bacharach E \& Ehrlich R 2005 Transferrin receptor colocalizes and interacts with the hemochromatosis factor (HFE) and the divalent metal transporter-1 (DMT1) in trophoblast cells. Journal of Cellular Physiology 204 901-912. (https://doi.org/10.1002/jcp.20349)

Gunshin H, Fujiwara Y, Custodio AO, Direnzo C, Robine S \& Andrews NC 2005 Slc11a2 is required for intestinal iron absorption and erythropoiesis but dispensable in placenta and liver. Journal of Clinical Investigation 115 1258-1266. (https://doi.org/10.1172/JCI24356)

Hindmarsh PC, Geary MP, Rodeck CH, Jackson MR \& Kingdom JC 2000 Effect of early maternal iron stores on placental weight and structure. Lancet 356 719-723. (https://doi.org/10.1016/s0140-6736(00)02630-1)

Huang A, Zhang R \& Yang Z 2001 Quantitative (stereological) study of placental structures in women with pregnancy iron-deficiency anemia. European Journal of Obstetrics, Gynecology, and Reproductive Biology 97 59-64. (https://doi.org/10.1016/s0301-2115(00)00480-2)

Hubbard AC, Bandyopadhyay S, Wojczyk BS, Spitalnik SL, Hod EA \& Prestia KA 2013 Effect of dietary iron on fetal growth in pregnant mice. Comparative Medicine 63 127-135.

Hvidberg V, Maniecki MB, Jacobsen C, Højrup P, Møller HJ \& Moestrup SK 2005 Identification of the receptor scavenging hemopexinheme complexes. Blood 106 2572-2579. (https://doi.org/10.1182/ blood-2005-03-1185)

letta F, Wu Y, Winter J, Xu J, Wang J, Post M \& Caniggia I 2006 Dynamic HIF1A regulation during human placental development. Biology of Reproduction 75 112-121. (https://doi.org/10.1095/ biolreprod.106.051557) 
Jaacks LM, Young MF, Essley BV, McNanley TJ, Cooper EM, Pressman EK, McIntyre AW, Orlando MS, Abkowitz JL, Guillet R et al. 2011 Placental expression of the heme transporter, feline leukemia virus subgroup $\mathrm{C}$ receptor, is related to maternal iron status in pregnant adolescents. Journal of Nutrition 141 1267-1272. (https://doi.org/10.3945/jn.110.135798)

Kadyrov M, Kosanke G, Kingdom J \& Kaufmann P 1998 Increased fetoplacental angiogenesis during first trimester in anaemic women. Lancet 352 1747-1749. (https://doi.org/10.1016/s0140-6736(98)020698)

Kiran N, Zubair A, Malik TM, Ayyub M \& Khan IM 2015 Placental morphology at different maternal hemoglobin levels: a histopathological study. Pakistan Armed Forces Medical Journal 65 189-193.

Kosanke G, Kadyrov M, Korr H \& Kaufmann P 1998 Maternal anemia results in increased proliferation in human placental villi. Placenta 19 339-357. (https://doi.org/10.1016/S0143-4004(98)80024-6)

Krantman HJ, Young SR, Ank BJ, O'Donnell CM, Rachelesfsky GS \& Stiehm ER 1982 Immune function in pure iron deficiency. American Journal of Diseases of Children 136 840-844. (https://doi.org/10.1001/ archpedi.1982.03970450082020)

Kroos MJ, Starreveld JS, Verrijt CE, van Eijk HG \& van Dijk JP 1996 Regulation of transferrin receptor synthesis by human cytotrophoblast cells in culture. European Journal of Obstetrics, Gynecology, and Reproductive Biology 65 231-234. (https://doi.org/10.1016/03012115(95)02368-2)

Kumar A, Rai AK, Basu S, Dash D \& Singh JS 2008 Cord blood and breast milk iron status in maternal anemia. Pediatrics 121 e673-e677. (https:// doi.org/10.1542/peds.2007-1986)

Lao TT \& Tam KF 2000 Placental ratio and anemia in third-trimester pregnancy. Journal of Reproductive Medicine 45 923-928.

Lao TT \& Wong WM 1997 Placental ratio - its relationship with mild maternal anaemia. Placenta 18 593-596. (https://doi.org/10.1016/01434004(77)90015-7)

Larsen S, Bjelland EK, Haavaldsen C \& Eskild A 2016 Placental weight in pregnancies with high or low hemoglobin concentrations. European Journal of Obstetrics, Gynecology, and Reproductive Biology 206 48-52. (https://doi.org/10.1016/j.ejogrb.2016.08.039)

Lelic M, Bogdanovic G, Ramic S \& Brkicevic E 2014 Influence of maternal anemia during pregnancy on placenta and newborns. Medical Archives 68 184-187. (https://doi.org/10.5455/medarh.2014.68.184-187)

Lelić M, Ramić S, Žigić Z, Bogdanović G \& Marković S 2014 Stereological analysis of terminal villi of the placentas of pregnant woman with sideropenic anemia. Bosnian Journal of Basic Medical Sciences $\mathbf{1 4}$ 139-143. (https://doi.org/10.17305/bjbms.2014.3.44)

Levytska K, Kingdom J, Baczyk D \& Drewlo S 2013 Heme oxygenase-1 in placental development and pathology. Placenta 34 291-298. (https:// doi.org/10.1016/j.placenta.2013.01.004)

Lewis RM, James LA, Zhang J, Byrne CD \& Hales CN 2001a Effects of maternal iron restriction in the rat on hypoxia-induced gene expression and fetal metabolite levels. British Journal of Nutrition 85 193-201. (https://doi.org/10.1079/bjn2000247)

Lewis RM, Doherty CB, James LA, Burton GJ \& Hales CN 2001b Effects of maternal iron restriction on placental vascularization in the rat. Placenta 22 534-539. (https://doi.org/10.1053/plac.2001.0679)

Li YQ, Yan H \& Bai B 2008 Change in iron transporter expression in human term placenta with different maternal iron status. European Journal of Obstetrics, Gynecology, and Reproductive Biology 140 48-54. (https:// doi.org/10.1016/j.ejogrb.2008.02.012)

Li YQ, Bai B, Cao XX, Yan H \& Zhuang GH 2012 Ferroportin 1 and hephaestin expression in BeWo cell line with different iron treatment. Cell Biochemistry and Function 30 249-255. (https://doi.org/10.1002/cbf.1843)

Lipiński P, Styś A \& Starzyński RR 2013 Molecular insights into the regulation of iron metabolism during the prenatal and early postnatal periods. Cellular and Molecular Life Sciences 70 23-38. (https://doi. org/10.1007/s00018-012-1018-1)

Lopez A, Cacoub P, Macdougall IC \& Peyrin-Biroulet L 2016 Iron deficiency anaemia. Lancet 387 907-916. (https://doi.org/10.1016/ S0140-6736(15)60865-0)

Malassiné A, Frendo JL \& Evain-Brion D 2003 A comparison of placental development and endocrine functions between the human and mouse model. Human Reproduction Update 9 531-539. (https://doi. org/10.1093/humupd/dmg043)
Maliepaard M, Scheffer GL, Faneyte IF, van Gastelen MA, Pijnenborg AC, Schinkel AH, van De Vijver MJ, Scheper RJ \& Schellens JH 2001 Subcellular localization and distribution of the breast cancer resistance protein transporter in normal human tissues. Cancer Research 61 3458-3464.

Mannaerts D, Faes E, Cos P, Briedé JJ, Gyselaers W, Cornette J, Gorbanev Y, Bogaerts A, Spaanderman M, Van Craenenbroeck E et al. 2018 Oxidative stress in healthy pregnancy and preeclampsia is linked to chronic inflammation, iron status and vascular function. PLOS ONE 13 e0202919. (https://doi.org/10.1371/journal.pone.0202919)

Maria de Regil L 2010 Haemoglobin Concentrations for the Diagnosis of Anaemia and Assessment of Severity. Geneva: World Health Organisation.

Martin ME, Nicolas G, Hetet G, Vaulont S, Grandchamp B \& Beaumont C 2004 Transferrin receptor $1 \mathrm{mRNA}$ is downregulated in placenta of hepcidin transgenic embryos. FEBS Letters $\mathbf{5 7 4}$ 187-191. (https://doi. org/10.1016/j.febslet.2004.08.010)

McArdle HJ, Lang C, Hayes H \& Gambling L 2011 Role of the placenta in regulation of fetal iron status. Nutrition Reviews 69 (Supplement 1) S17-S22. (https://doi.org/10.1111/j.1753-4887.2011.00428.x)

McLean E, Cogswell M, Egli I, Wojdyla D \& de Benoist B 2009 Worldwide prevalence of anaemia, WHOVitamin and Mineral Nutrition Information System, 1993-2005. Public Health Nutrition 12 444-454.

Means RT 2020 Iron deficiency and iron deficiency anemia: implications and impact in pregnancy, fetal development, and early childhood parameters. Nutrients 12 447. (https://doi.org/10.3390/nu12020447)

Michalitsi V, Dafopoulos K, Gourounti K, Messini C, loannou M, Christodoulaki C, Panagopoulos P \& Messinis I 2015 Hypoxiainducible factor- $1 \alpha$ (HIF-1 $\alpha$ ) expression in placentae of women with iron deficiency anemia and $\beta$-thalassemia trait. Journal of Maternal-Fetal and Neonatal Medicine 28 470-474. (https://doi.org/10.3109/14767058.20 14.921672)

Milman N 2006a Iron and pregnancy - a delicate balance. Annals of Hematology 85 559-565. (https://doi.org/10.1007/s00277006-0108-2)

Milman N $2006 b$ Iron prophylaxis in pregnancy - general or individual and in which dose? Annals of Hematology 85 821-828. (https://doi. org/10.1007/s00277-006-0145-x)

Milman N, Bergholt T, Byg KE, Eriksen L \& Graudal N 1999 Iron status and iron balance during pregnancy. A critical reappraisal of iron supplementation. Acta Obstetricia et Gynecologica Scandinavica $\mathbf{7 8}$ 749-757.

Moe S, Grill AK \& Allan GM 2019 Newer iron supplements for anemia. Canadian Family Physician Medecin de Famille Canadien 65556.

Mongia SM, Jain SK \& Yadav M 2011 Placenta: the wonder organ. Journal of the Indian Academy of Forensic Sciences 33 140-143.

Moretti D, Goede JS, Zeder C, Jiskra M, Chatzinakou V, Tjalsma H, MelseBoonstra A, Brittenham G, Swinkels DW \& Zimmermann MB 2015 Oral iron supplements increase hepcidin and decrease iron absorption from daily or twice-daily doses in iron-depleted young women. Blood 126 1981-1989. (https://doi.org/10.1182/blood-2015-05-642223)

Nausheen Rumana ASAK 2012 A study of histo pathological changes of placenta in severe anaemia. Journal of Evolution of Medical and Dental Sciences 1 616-623. (https://doi.org/10.14260/jemds/97)

Nemeth E \& Ganz T 2006 Regulation of iron metabolism by hepcidin. Annual Review of Nutrition 26 323-342. (https://doi.org/10.1146/ annurev.nutr.26.061505.111303)

Nemeth E, Tuttle MS, Powelson J, Vaughn MB, Donovan A, Ward DM, Ganz T \& Kaplan J 2004 Hepcidin regulates cellular iron efflux by binding to ferroportin and inducing its internalization. Science 306 2090-2093. (https://doi.org/10.1126/science.1104742)

Nicolas G, Bennoun M, Porteu A, Mativet S, Beaumont C, Grandchamp B, Sirito M, Sawadogo M, Kahn A \& Vaulont S 2002 Severe iron deficiency anemia in transgenic mice expressing liver hepcidin. PNAS 99 4596-4601. (https://doi.org/10.1073/pnas.072632499)

Ohgami RS, Campagna DR, McDonald A \& Fleming MD 2006 The steap proteins are metalloreductases. Blood 108 1388-1394. (https://doi. org/10.1182/blood-2006-02-003681)

Parkkila S, Waheed A, Britton RS, Bacon BR, Zhou XY, Tomatsu S, Fleming RE \& Sly WS 1997 Association of the transferrin receptor in human placenta with HFE, the protein defective in hereditary 
hemochromatosis. PNAS 94 13198-13202. (https://doi.org/10.1073/ pnas.94.24.13198)

Pasricha SR, Hayes E, Kalumba K \& Biggs BA 2013 Effect of daily iron supplementation on health in children aged 4-23 months: a systematic review and meta-analysis of randomised controlled trials. Lancet: Global Health 1 e77-e86. (https://doi.org/10.1016/S2214-109X(13)70046-9)

Qiu A, Jansen M, Sakaris A, Min SH, Chattopadhyay S, Tsai E, Sandoval C, Zhao R, Akabas MH \& Goldman ID 2006 Identification of an intestinal folate transporter and the molecular basis for hereditary folate malabsorption. Cell 127 917-928. (https://doi.org/10.1016/j. cell.2006.09.041)

Rehu M, Punnonen K, Ostland V, Heinonen S, Westerman M, Pulkki K \& Sankilampi U 2010 Maternal serum hepcidin is low at term and independent of cord blood iron status. European Journal of Haematology 85 345-352. (https://doi.org/10.1111/j.1600-0609.2010.01479.x)

Renaud SJ, Karim Rumi MA \& Soares MJ 2011 Review: genetic manipulation of the rodent placenta. Placenta 32 (Supplement 2) S130-S135. (https:// doi.org/10.1016/j.placenta.2010.12.017)

Reshetnikova OS, Burton GJ \& Teleshova OV 1995 Placental histomorphometry and morphometric diffusing capacity of the villous membrane in pregnancies complicated by maternal iron-deficiency anemia. American Journal of Obstetrics and Gynecology 173 724-727. (https://doi.org/10.1016/0002-9378(95)90330-5)

Rusia U, Bhatia A, Kapoor S, Madan N, Nair V \& Sood SK 1988 Placental morphology and histochemistry in iron deficiency anemia. Indian Journal of Medical Research 87 468-474.

Sangkhae V \& Nemeth E 2017 Regulation of the iron homeostatic hormone hepcidin. Advances in Nutrition 8 126-136. (https://doi.org/10.3945/ an.116.013961)

Sangkhae V \& Nemeth E 2019 Placental iron transport: the mechanism and regulatory circuits. Free Radical Biology and Medicine 133 254-261. (https://doi.org/10.1016/j.freeradbiomed.2018.07.001)

Sangkhae V, Fisher AL, Wong S, Koenig MD, Tussing-Humphreys L, Chu A, Lelić M, Ganz T \& Nemeth E 2020a Effects of maternal iron status on placental and fetal iron homeostasis. Journal of Clinical Investigation 130 625-640. (https://doi.org/10.1172/JCl127341)

Sangkhae V, Fisher AL, Chua KJ, Ruchala P, Ganz T \& Nemeth E $2020 b$ Maternal hepcidin determines embryo iron homeostasis. Blood In press. (https://doi.org/10.1182/blood.2020005745)

Santiago P 2012 Ferrous versus ferric oral iron formulations for the treatment of iron deficiency: a clinical overview. ScientificWorld/ournal 2012 846824. (https://doi.org/10.1100/2012/846824)

Singla PN, Chand S, Khanna S \& Agarwal KN 1978 Effect of maternal anaemia on the placenta and the newborn infant. Acta Paediatrica Scandinavica 67 645-648. (https://doi.org/10.1111/j.1651-2227.1978. tb17816.x)

Soares MJ, Chakraborty D, Karim Rumi MA, Konno T \& Renaud SJ 2012 Rat placentation: an experimental model for investigating the hemochorial maternal-fetal interface. Placenta 33 233-243. (https://doi. org/10.1016/j.placenta.2011.11.026)

Soncin F, Khater M, To C, Pizzo D, Farah O, Wakeland A, Arul Nambi Rajan K, Nelson KK, Chang CW, Moretto-Zita M et al. 2018 Comparative analysis of mouse and human placentae across gestation reveals species-specific regulators of placental development. Development $\mathbf{1 4 5}$ dev156273. (https://doi.org/10.1242/dev.156273)

Stanek J 2013 Hypoxic patterns of placental injury: a review. Archives of Pathology and Laboratory Medicine 137 706-720. (https://doi. org/10.5858/arpa.2011-0645-RA)

Stevens GA, Finucane MM, De-Regil LM, Paciorek CJ, Flaxman SR, Branca F, Peña-Rosas JP, Bhutta ZA, Ezzati M \& Nutrition Impact Model Study Group (Anaemia) 2013 Global, regional, and national trends in haemoglobin concentration and prevalence of total and severe anaemia in children and pregnant and non-pregnant women for 1995-2011: a systematic analysis of population-representative data. Lancet: Global Health 1 e16-e25. (https://doi.org/10.1016/S2214-109X(13)70001-9)

Tarrade A, Panchenko P, Junien C \& Gabory A 2015 Placental contribution to nutritional programming of health and diseases: epigenetics and sexual dimorphism. Journal of Experimental Biology 218 50-58. (https:// doi.org/10.1242/jeb.110320)

Toblli JE, Cao G, Oliveri L \& Angerosa M 2012 Effects of iron deficiency anemia and its treatment with iron polymaltose complex in pregnant rats, their fetuses and placentas: oxidative stress markers and pregnancy outcome. Placenta 33 81-87. (https://doi.org/10.1016/j. placenta.2011.11.017)

Tolkien Z, Stecher L, Mander AP, Pereira DIA \& Powell JJ 2015 Ferrous Sulfate supplementation causes significant gastrointestinal side-effects in adults: a systematic review and meta-analysis. PLOS ONE 10 e0117383. (https://doi.org/10.1371/journal.pone.0117383)

van Santen S, Kroot JJC, Zijderveld G, Wiegerinck ET, Spaanderman MEA \& Swinkels DW 2013 The iron regulatory hormone hepcidin is decreased in pregnancy: a prospective longitudinal study. Clinical Chemistry and Laboratory Medicine 51 1395-1401. (https://doi.org/10.1515/cclm2012-0576)

Venkata Surekha M, Sujatha T, Gadhiraju S, Kotturu SK, Siva Prasad M, Sarada K, Bhaskar V \& Uday Kumar P 2020 Effect of maternal iron deficiency anaemia on the expression of iron transport proteins in the third trimester placenta. Fetal and Pediatric Pathology 1-16. (https://doi. org/10.1080/15513815.2020.1725942)

Walter PB, Knutson MD, Paler-Martinez A, Lee S, Xu Y, Viteri FE \& Ames BN 2002 Iron deficiency and iron excess damage mitochondria and mitochondrial DNA in rats. PNAS 99 2264-2269. (https://doi. org/10.1073/pnas.261708798)

Willemetz A, Lenoir A, Deschemin JC, Lopez-Otin C, Ramsay AJ, Vaulont S \& Nicolas G 2014 Matriptase-2 is essential for hepcidin repression during fetal life and postnatal development in mice to maintain iron homeostasis. Blood 124 441-444. (https://doi.org/10.1182/ blood-2014-01-551150)

Williams LA, Evans SF \& Newnham JP 1997 Prospective cohort study of factors influencing the relative weights of the placenta and the newborn infant. BMJ 314 1864-1868. (https://doi.org/10.1136/ bmj.314.7098.1864)

Woo KJ, Lee TJ, Park JW \& Kwon TK 2006 Desferrioxamine, an iron chelator, enhances HIF-1alpha accumulation via cyclooxygenase-2 signaling pathway. Biochemical and Biophysical Research Communications 343 8-14. (https://doi.org/10.1016/j.bbrc.2006.02.116)

Woodman AG, Care AS, Mansour Y, Cherak SJ, Panahi S, Gragasin FS \& Bourque SL 2017 Modest and severe maternal iron deficiency in pregnancy are associated with fetal anaemia and organ-specific hypoxia in rats. Scientific Reports 7 46573. (https://doi.org/10.1038/srep46573)

Woodman AG, Mah R, Keddie D, Noble RMN, Panahi S, Gragasin FS, Lemieux H \& Bourque SL 2018 Prenatal iron deficiency causes sexdependent mitochondrial dysfunction and oxidative stress in fetal rat kidneys and liver. FASEB Journal 32 3254-3263. (https://doi.org/10.1096/ fj.201701080R)

Young MF, Pressman E, Foehr ML, McNanley T, Cooper E, Guillet R, Orlando M, McIntyre AW, Lafond J \& O'Brien KO 2010 Impact of maternal and neonatal iron status on placental transferrin receptor expression in pregnant adolescents. Placenta 31 1010-1014. (https:// doi.org/10.1016/j.placenta.2010.08.009)

Young MF, Griffin I, Pressman E, McIntyre AW, Cooper E, McNanley T, Harris ZL, Westerman M \& O'Brien KO 2012 Maternal hepcidin is associated with placental transfer of iron derived from dietary heme and nonheme sources. Journal of Nutrition 142 33-39. (https://doi. org/10.3945/jn.111.145961)

Received 17 May 2020

First decision 22 June 2020

Revised manuscript received 3 August 2020

Accepted 6 August 2020 